\title{
Renewable Marine Energies in Galicia: Potential and Monitoring Tools
}

\author{
Primitivo B. González ${ }^{1}$, Santiago Martín ${ }^{1}$, Ana Álvarez ${ }^{1}$ and Cristina Anido ${ }^{2}$ \\ ${ }^{1}$ Departamento de Construcciones Navales \\ ${ }^{1,2}$ Grupo de Innovaciones Marinas \\ Universidade da Coruña \\ Campus de Serantes - Ferrol, 15405 A Coruña (Spain) \\ Phone: +34 981337400 Fax number: +34 981337401 \\ E-mail: primitif@cdf.udc.es, smartinc@udc.es, aalvarez@udc.es, cristina.anido@udc.es
}

\begin{abstract}
The energy debate is characterized by the consideration of a great variety of arguments. However, nowadays, a certain consensus is reached when demanding the necessary coexistence of different generation sources in the energy mix, in order to guarantee the supply, hold the costs or reduce the $\mathrm{CO}_{2}$ emissions. Considering this framework, the use of renewable energies seems to be obvious: they are abundant, domestic and their contribution to the fight against the climate change is unquestionable.
\end{abstract}

The ocean, covers a $75 \%$ of the earth's surface, represents a huge reserve of solar and gravitational energy, still to be exploited, estimated in a minimum value of $25.000 \mathrm{GW}$. The waves, tides and winds of the seas that border the north coast of the Iberian Peninsula are rough and offer a huge kinetic energy potential. Furthermore, Galicia benefits from its consolidated shipbuilding and maritime tradition and port infrastructures, its experience in the onshore wind energy sector, as well as from the available industrial resources and technologies.

By analysing previous reports, the present paper aims to identify the Galicia potential for the use of renewable marine energies, specifically coming from waves, tidal streams and offshore winds, and provide monitoring tools for the surveillance of critical elements, as well as for R\&D funding sources.

\section{Key words}

Renewable marine energies, Environmental regulations, R\&D and innovation, Galicia.

\section{Introduction}

We are currently living in a consumer society in growing expansion, in the technology era, where the need of energy is non avoidable [1]. It is worldwide recognized that the usual energy resources are finite and that this fact implies one of the main problems: the present energy model, depending basically on fossil fuels, is unsustainable in its economic, environmental and social dimension.

The experts suggest as the most urgent action lines the energy saving and efficiency, as well as the extension of the use of alternative renewable energies. So, a sustainable solution is glimpsed in natural and inexhaustible resources such as the wind, the sun, the rivers or the seas.

While the hydraulic, solar and wind energies are the most developed, and the biomass, biofuels and geothermal energy are getting more supporters, the marine energies are still on its stages of research and development.

The ocean, which takes up nearly $80 \%$ of the total earth's surface, represents a huge reserve of solar and gravitational energy. Its exploitation turns into an interesting challenge for the future, as it is one of the less exploited energy resources at the present time. The internal operation of the energy conversion systems, their installations, operation and maintenance and the design of electric substations are a challenge not only for researchers but also for technologists.

For many coastal regions, with large environmental value, this type of energy could represent the possibility for economic, social and industrial growth, without impairing or affecting the environment. The waves and tides of the seas that border the north coast of the Iberian Peninsula, especially in Galicia, are offering a huge kinetic energy potential.

The Chairman, of Puertos de Galicia in 2006 had already recognized the germ of what could be an entirely Galician leading industry: "We are about to create a real industry and complete the exploitation cycle of the waves energy in favour of the region progress. Galicia starts from a privileged position and finds a strategic opportunity to develop said big potential resource”.

Considering the above-described framework, the objectives of the present paper are:

- Identify Galicia’s potential for the use of renewable marine energies, specifically coming from waves, tidal streams and offshore winds.

- Provide monitoring tools for the surveillance of critical elements. 
- Provide monitoring tools for funding sources to the $\mathrm{R} \& \mathrm{D}$ and innovation.

\section{Galicia's Potential}

\section{A. Energy Mix}

The total primary energy represents the sum of primary energy produced within the region and imported from the rest of Spain and other countries, as well as the variations in the stocks of the considered items.

Concerning Galicia, trade balance is always negative, since it does not export any type of energy raw material. On another hand, imports focus on non-renewable energies such as crude oil, petroleum products and coal.

The following table reflects the Galician energy mix in kilotons of oil equivalent (ktoe) in 2006, according to the latest report published by the Instituto Enerxético de Galicia [1] (INEGA - www.inega.es).

Table I: Primary energy in Galicia (ktoe) [2].

(a) Superior Calorific Power (SCP). (b) Big and mini hydro, wind, sun and bio-mass and bio-mass waste.

\begin{tabular}{|l|c|c|c|}
\hline Primary Energy & Produced & Imported & Total \\
\hline Crude oil & 0 & 5.040 & 5.040 \\
\hline Petroleum products & 0 & 2.814 & 2.814 \\
\hline Coal & 1.366 & 1.709 & 3.075 \\
\hline Natural gas (a) & 0 & 567 & 567 \\
\hline Electricity & 0 & 320 & 320 \\
\hline Water - Big hydro & 608 & 0 & 608 \\
\hline Water - Mini hydro & 70 & 0 & 70 \\
\hline Bio-mass and bio-mass waste & 447 & 143 & 590 \\
\hline Bio-fuel & 0 & 0,9 & 0,9 \\
\hline Waste and residual energies & 112 & 0 & 112 \\
\hline Wind & 533 & 0 & 533 \\
\hline Sun & 1 & 0 & 1 \\
\hline Total Renewable Energy (b) & $\mathbf{1 . 6 5 9}$ & $\mathbf{1 4 3}$ & $\mathbf{1 . 8 0 2}$ \\
\hline Total Non Renewable Energy & $\mathbf{1 . 4 7 8}$ & $\mathbf{1 0 . 4 5 1}$ & $\mathbf{1 1 . 9 2 9}$ \\
\hline Total Primary Energy & $\mathbf{3 . 1 3 7}$ & $\mathbf{1 0 . 5 9 4}$ & $\mathbf{1 3 . 7 3 1}$ \\
\hline
\end{tabular}

\section{B. Resources}

The Galician coast has a varied morphology: bays alternate with headlands, sandy areas with cliffs and marshes, open coast with sheltered shorelines. The rias, distinctive feature of the Galician coastline, compensate the narrowness of the continental shelf.

A determining factor, when developing a project for the exploitation of renewable marine energies (RME), is to define the level of existing and available resources.

Offshore Wind. Northern Europe offers the best resources: strong winds that have travelled long distances. Thus, at the corner of the Iberian Peninsula, Galicia benefits from particularly favourable conditions for the exploitation of offshore wind power.

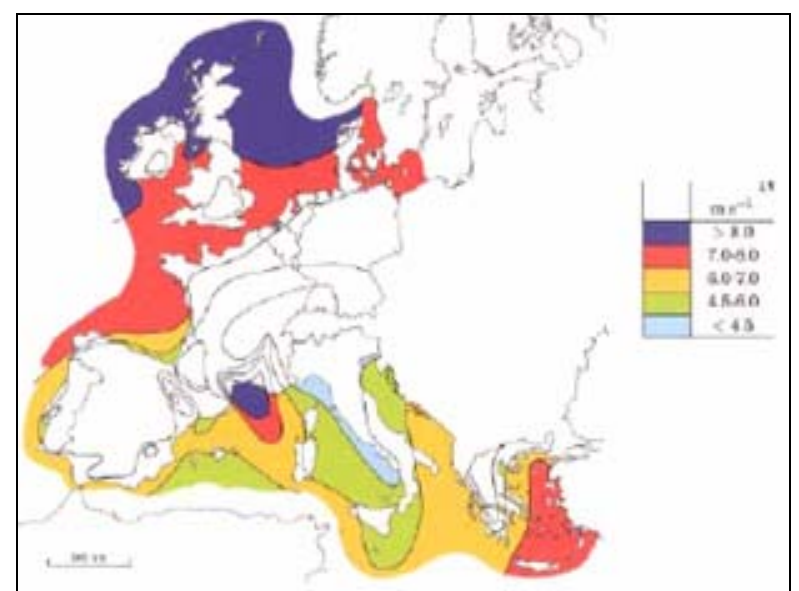

Figure 1: European seas average wind speed [3].

However, considering the morphology of its shelf, steep and narrow, as well as technical limitations, to date, in the implementation of an offshore wind turbine (depths below $30 \mathrm{~m}$ ), offshore wind farms would be located near the coast. A possible solution for this situation lies in the use of turbines adapted to the exploitation of wind resources in deep water.

Waves. Galicia is considered the European continental community with higher wave resources for their energy use.
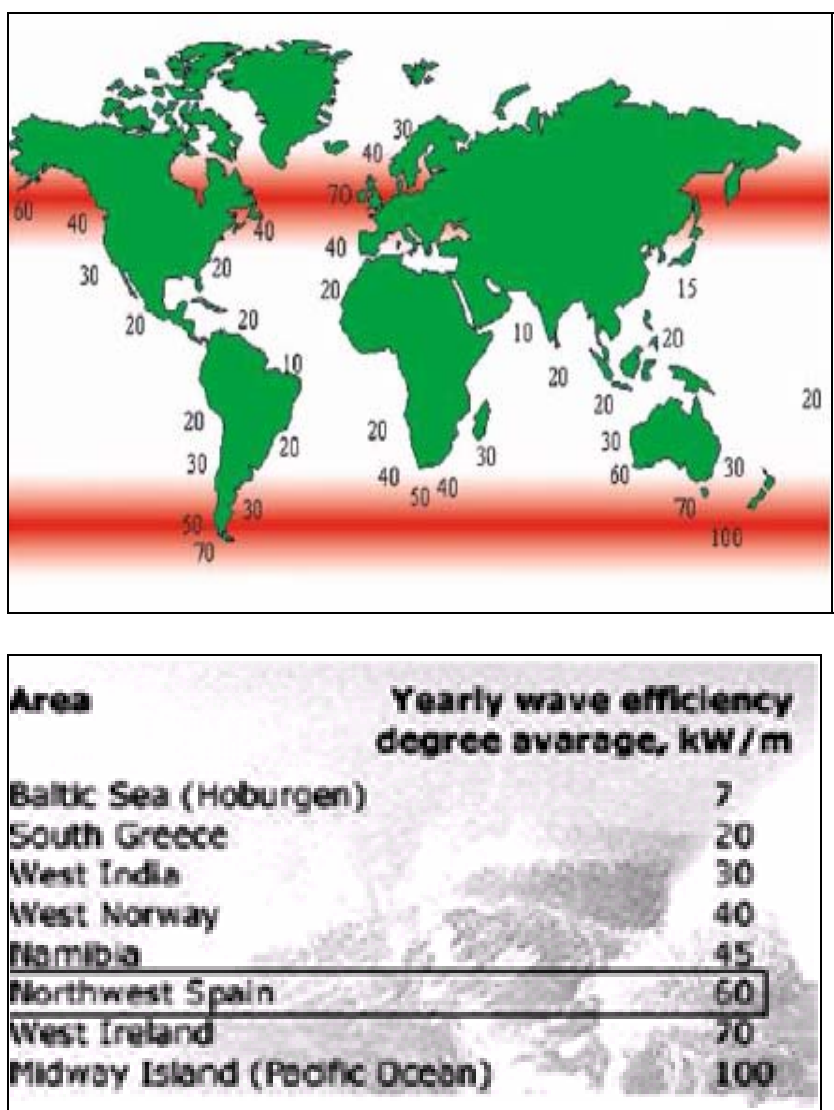

Figure 2: Worldwide waves energy potential distribution in open sea $(\mathrm{kW} / \mathrm{m})$. Source: Seapower International AB. 




\begin{tabular}{|l|}
1 \\
2 United Kingdom \\
2 Spain/Portugal \\
3 Chile \\
4 Ireland \\
5 Oceania \\
6 France \\
7 USA \\
\hline
\end{tabular}

Figure 3: European waves energy potential distribution in open sea $(\mathrm{kW} / \mathrm{m})$. Source: Independent Natural Resource Inc.

It is worth highlighting the Galician maritime climate study conducted by Norvento. It gathers together information on different wave generation models and waves data in real time, obtained by a Waverider directional buoy. It concludes that the average power available in the near-coastal sites is medium-depth, very suitable for its energy exploitation.

Moreover, MeteoGalicia and INEGA are the promoters of the "Atlas de ondas de Galicia" (2005-2009). This project is based on a statistical study of the availability of stored energy in the waves that border the Galician coast. The results show that this potential presents a great variability, both temporal and spatial.

Finally, the Port Authority of A Coruña and Ferrol have the Sistema Autónomo de Predicción de Oleaje (SAPO), which allows local wave prediction throughout 48 hours, considering the changes induced by the coastline and the continental shelf.

Tidal streams. Existing studies indicate that the average level of marine currents along the Galician coast is low for its energy use. It might be interesting to study some specific sites, such as the outflow of the rias or interisland areas, which might have a relevant resource level, but, in these cases, the projects might be unfeasible due to their environmental impact.

\section{Socioeconomic Aspects}

The nearly 1500 kilometres of the Galician coastline agglutinate a great variety of different socioeconomic actors $[4,5]$.

From an environmental standpoint, it is worth pointing out the Galician protected natural areas network, which represents over $12 \%$ of the Autonomous Region area. The regional rules governing the environment and landscape protection are contained in the Law 9/2001 of Nature Conservation.

Moreover, the fisheries sector, which includes all activities related to extractive fishing, shellfishing, aquaculture and related industries, remains one of the main economic agents in Galicia (1.98\% of GDP). According to data from the Statistical Services of the Xunta, the turnover of this sector exceeded 4,750 million of euros in 2007. In addition to direct billing, this activity stimulates the running of many other economic agents: canning industry, shipbuilding, trade, etc. It is estimated that each offshore job generates four additional onshore jobs.

There is thus a strong interaction between the RME development and socioeconomic factors, related not only to fisheries, but also to leisure activities: navigation, water sports, tourist use of beaches and coastline in general, etc.

On another hand, the development of projects for the RME energy use would be an important economic diversification of coastal areas, creating direct employment in the business network and manufacturing industry of devices and components, installation and operation and maintenance, as well as indirect employment [6].

\section{System}

The RME development could highly benefit from the Galician R\&D System, in particular from the creation of the Rede Galega de Plataformas Tecnolóxicas (NEURONA - www.redeneurona.org) promoted by the Autonomous Administration. Platforms are groups of entities, which aim to boost the competitiveness of key sectors in the Galician economy through collaboration and integration of actions; some of them are directly related to the RME development, such as the Plataforma Tecnolóxica Galega de Enerxía (ENERXE www.enerxe.org) and the Plataforma Tecnolóxica Galega de Medio Ambiente (ENVIT - www.envite.org).

\section{E. Development Actors}

Galicia has numerous Science and Technology Centres, some of them taking an active role in the RME development, for instance, the Centro Tecnológico del Mar (CETMAR - www.cetmar.org) and the Centro Tecnolóxico do Naval Galego (CETNAGA www.cetnaga.es). The Autonomous Region also has the opportunity to leverage existing synergies with other sectors, such as wind power and shipbuilding.

The high potential concerning energy and environment aspects represents an incentive for firms and other entities, among which it is worth mentioning: Norvento (www.norvento.com) or the Agrupación Empresarial Innovadora Enerxía e Medio Ambiente Sostible desde Galicia (AEI Enermas - www.enermas.eu), germ of the Galician Energy and Environment Cluster. 
Finally, last but not least, the three Galician universities play an important role in developing research activities: A Coruña University (UDC), Vigo University (UVI), Santiago de Compostela University (USC).

\section{F. Demonstration Tanks}

The Escuela Politécnica Superior of the Santiago de Compostela University has a demonstration channel equipped with a paddle-type wavemaker piston, for regular and irregular waves, and an Active Wave Absorption Control System (AWACS).

The Centro de Innovación Tecnológica en Edificación e Ingeniería Civil (CITEEC) of the A Coruña University develops research activities in different departments. The Department of Ports and Coasts has a demonstration channel and dock capable of generating real random waves and currents. The Laboratory of Aeroelastic Studies has a wind tunnel with a $60 \mathrm{HP}$ engine capable of producing an air flow of up to $33 \mathrm{~m}^{3} / \mathrm{s}$ with a maximum speed of $32 \mathrm{~m} / \mathrm{s}$ and a turbulence level less than $0.5 \%$.

\section{G. Demonstration Projects}

The company Galicia Mar Renovables has developed the first prototype of a buoy (scale 1:10) for the production of wave energy; it will build two other prototypes before launching the industrial stage. The Ministerio de Industria promoted this initiative by providing a loan of 2.1 million of euros. The registered office of the company is located in Ferrol, area selected for its high labour specialization, the availability of Science and Technology Centres, as well as for the characteristics of the coast.

On another hand, different Galician entities collaborate in developing a system with multiple captures for the transformation of ocean wave energy, in the frame of the PSE-MAR Project.

\section{H. Projects in Development}

Installation of an experimental wave farm in the Galician northwest coast with Pelamis conversion technology. The project is currently under administrative planning to obtain necessary permits and concessions. The initial power to be installed is $2.25 \mathrm{MW}$.

Development of the patented technology WaveCat ${ }^{\mathrm{TM}}$, based on the wave overtopping principle (OTD). This device has been collaboratively developed by the USC, the UDC, the CIS Galicia, Norvento and Vicus DT.

Study for the development of operation and maintenance strategies in RME facilities and their implementation in Galicia (UDC).

Development of Oscillating Water Column (OWC) technology in the port of A Guardia by the firm Sea Energy.
Although the average level of marine currents along the Galician coast is low for its energy use, the Plataforma Tecnolóxica Galega de Enerxía (ENERXE) mentions in its Strategic Agenda [7] the design of a system which allows the currents energy use, minimizing the environmental impact, and defines the tidal streams map of the Galician coast.

\section{Monitoring Tools}

\section{A. Technology}

To maintain an updated knowledge on the status and development of renewable energies in general, and the use of RME in particular, it is important to ensure the continuous and systematic monitoring of critical factors. Table II provides some representative cases.

Table II: Some associations, events, projects and publications to be monitored.

\begin{tabular}{|c|c|}
\hline \multicolumn{2}{|l|}{ ENTITIES } \\
\hline $\begin{array}{l}\text { Agence de l'Environnement et } \\
\text { de la Maîtrise de l'Énergie }\end{array}$ & $\underline{\text { www.ademe.fr }}$ \\
\hline $\begin{array}{l}\text { Centro Investigaciones } \\
\text { Energéticas, Medioambientales } \\
\text { y Tecnológicas }\end{array}$ & $\underline{\text { www.ciemat.es }}$ \\
\hline $\begin{array}{l}\text { Centro Nacional de Energías } \\
\text { Renovables }\end{array}$ & $\underline{\text { www.cener.com }}$ \\
\hline European Marine Energy Centre & www.emec.org.uk \\
\hline $\begin{array}{lll}\text { European } & \text { Ocean } & \text { Energy } \\
\text { Association } & & \\
\end{array}$ & www.eu-oea.com \\
\hline $\begin{array}{ll}\text { International } & \text { Electrotechnical } \\
\text { Commission } & \end{array}$ & $\underline{\text { www.iec.ch }}$ \\
\hline $\begin{array}{l}\text { International Energy Agency - } \\
\text { Ocean Energy Systems }\end{array}$ & www.iea-oceans.org \\
\hline $\begin{array}{l}\text { International Renewable Energy } \\
\text { Agency }\end{array}$ & www.irena.org \\
\hline Maritime Research Institute & www.marin.nl \\
\hline $\begin{array}{l}\text { Observatoire des Énergies } \\
\text { Renouvelables } \text { Observ’ER }\end{array}$ & $\begin{array}{l}\text { www.energies- } \\
\text { renouvelables.org }\end{array}$ \\
\hline \multicolumn{2}{|l|}{ EVENTS } \\
\hline $\begin{array}{l}\text { European Renewable Energy } \\
\text { Policy Conference }\end{array}$ & $\begin{array}{l}\text { www.erec.org/welcome. } \\
\text { html }\end{array}$ \\
\hline $\begin{array}{lll}\begin{array}{l}\text { European } \\
\text { Conferences }\end{array} & \text { Wind } & \text { Energy } \\
\end{array}$ & www.ewec.info \\
\hline $\begin{array}{lll}\text { International } & \text { Wave } & \text { Energy } \\
\text { Summit IWES } & & \\
\end{array}$ & $\begin{array}{l}\text { www.waveenergytoday. } \\
\text { com/IWES }\end{array}$ \\
\hline \multicolumn{2}{|l|}{ EUROPEAN PROJECTS } \\
\hline $\begin{array}{l}\text { Aquatic Renewable Energy } \\
\text { Technologies }\end{array}$ & www.aquaret.com \\
\hline $\begin{array}{lll}\text { Components for } & \text { Ocean } \\
\text { Renewable } & & \\
\text { Energy Systems } & & \\
\end{array}$ & $\underline{\underline{\text { hrmc.ucc.ie/FP7/cores.h }}}$ \\
\hline $\begin{array}{l}\text { Equitable Testing and } \\
\text { Evaluation of Marine Energy } \\
\text { Extraction Devices in terms of } \\
\text { Performance, Cost and } \\
\text { Environmental Impact }\end{array}$ & www.equimar.org \\
\hline $\begin{array}{l}\text { Initial Training } \text { Network for } \\
\text { Wave Energy } \\
\text { Professionals }\end{array}$ & $\underline{\text { www.wavetrain2.eu }}$ \\
\hline SuperGen Marine & $\frac{\text { www.supergen- }}{\text { marine.org.uk }}$ \\
\hline $\begin{array}{l}\text { WAVe Energy PLAnning and } \\
\text { Marketing }\end{array}$ & www.waveplam.eu \\
\hline
\end{tabular}




\begin{tabular}{|l|l|}
\hline PUBLICATIONS & www.energiadiario.com \\
\hline Energía Diario & $\begin{array}{l}\text { www.energias- } \\
\text { renovables.com }\end{array}$ \\
\hline Energías Renovables & $\underline{\text { www.infopower.es }}$ \\
\hline InfoPOWER & $\underline{\text { ec.europa.eu/energy/inte }}$ \\
\hline $\begin{array}{l}\text { Intelligent Energy News } \\
\text { Review }\end{array}$ & $\underline{ }$ \\
\hline
\end{tabular}

\section{B. State of the art}

The report entitled "Des énergies marines en Bretagne: à nous de jouer!" [8], developed by the Conseil Economique et Social de la Bretagne, offers an interesting overview on different devices, and their promoter, for the RME energy use.

\section{Politics and Laws}

The installation and operation of devices for the RME energy use require, as a first step, the identification of the applicable laws. There are different technologies and many prototypes, but their location is the main criterion that determines the legal system, as well as the authorities and stakeholders involved.

Currently, in Galicia, the coast is a complex area where different authorities are involved: State, Autonomous Regions and Municipalities [9]. However, sate rules are the most commonly applied:

Royal Decree 1028/2007 of 20 July, establishes the administrative procedure for processing applications for the authorisation of electricity generating facilities in territorial waters.

Royal Decree 661/2007 of 25 May, governs electricity production subject to the special regime.

Law 22/1988 of 28 July, on Coasts, together with the Royal Decree 1471/1989, determine, regulate, protect and safeguard the public use of coasts and jurisdictional waters.

Royal Decree 1/2008 of 11 January, approving the consolidated text of the Law on the Environmental Impact of Projects.

Law 26/2007 of 23 October on Environmental Responsibility.

Law 9/2006 of 28 April, on the assessment of the effects of certain plans and programmes.

At the European level it is worth highlighting:

Directive 2009/28/EC of 23 April, on the promotion of the use of energy from renewable sources.

Directive 97/11/EC of 3 March, on the assessment of the effects of certain public and private projects on the environment.
Directive 2003/35/EC of 26 May, providing for public participation in respect of the drawing up of certain plans and programmes relating to the environment.

On another hand, from a political standpoint, different state and regional policies are being developed:

Renewable Energy Plan 2005-2010; the update for the period 2011-2020 is currently in process.

2008-2012 Action Plan for the Strategy of Energy Saving and Efficiency in Spain (E4) [10].

\section{Galicia Energy Plan 2007-2012.}

Environmental Strategic Study for the Spanish coast Offshore wind map. As previously mentioned, the Galician Parliament has recently declared against the exploitation of offshore wind energy.

\section{Funding Sources}

\section{A. Regional}

The Plan Galego de Investigación, Desenvolvemento e InnovaciónTecnolóxica 2006-2010 (INCITE) [11], with an initial budget of 800 million euros, aims to promote the economic growth and social development of Galicia by improving its scientific and technological capacity. It considers five operational areas: financing, human capital, added-value research, Galician innovation system and culture, communication and awareness.

\section{B. National}

The Plan Nacional de Investigación Científica, Desarrollo e Innovación Tecnológica 2008-2011 [12] aims to provide research, development and innovation activities for the service of citizenship, social welfare and sustainable development, with full and equal inclusion of women. It considers four operational areas: knowledge and skills generation, R\&D cooperation, technological development and innovation and strategic actions.

\section{European}

The Seventh Framework Program for Research and Technological Development 2007-2013, with a budget of 50,500 million euros, considers four specific programs, as well as a specific nuclear research programme: Cooperation, Ideas, People and Capacities.

The Intelligent Energy Europe Program 2007-2013, with an overall budget of 730 million euros, is part of the Competitiveness and Innovation Framework Program (CIP). It is intended to support projects designed to help achieve the goals of energy and climate change for 2020: $20 \%$ reduction in greenhouse gases emissions, 20\% increase in energy efficiency, $20 \%$ renewable energies. Projects with high visibility are particularly interesting, in order to widely provide technologies and create suitable 
market conditions for their use, as well as identify market failures and provide solutions.

The Strategic Energy Technology Plan (SET-Plan) aims to accelerate the development and wide-scale application of low-carbon energy technologies for the achievement of the EU's set energy and climate goals for 2020, and to position the European industry in a leading position worldwide while contributing to the transition to a lowcarbon economy by 2050. It proposes six European Industrial Initiatives (EIIs): wind, solar, bioenergy, electricity grids carbon capture and storage and nuclear fission. The Commission is examining other avenues with great potential such as other sources of offshore renewable energy (waves, tides, currents and thermal gradients).

\section{Conclusions}

The energy debate is characterized by the consideration of a great variety of arguments. However, nowadays, a certain consensus is reached when demanding the necessary coexistence of different generation sources in the energy mix, in order to guarantee the supply, hold the costs or reduce the $\mathrm{CO}_{2}$ emissions. Considering this framework, the use of renewable energies seems to be obvious: they are abundant, domestic and their contribution to the fight against the climate change is unquestionable

Considering its great potential, the RME sector positions itself as a market of interest. Galicia is characterized by a high level of resource and benefits from its long shipbuilding and maritime tradition and port infrastructures, its experience in the onshore wind sector, as well as from the available industrial resources and technologies.

It is essential to realize the potential of this new sector and its subsequent translation into wealth and employment. The RME energy use implies an economic development opportunity, linked to production and deployment of new technologies, allowing on the other hand the diversification of mature sectors.

In conclusion, Galicia has a high potential to be at the forefront of research into RME energy use. From a strategic perspective, the Autonomous Region should take advantage of all the identified strengths and opportunities to pursue leadership in technology development and the consecution of commercial prototypes, in order to be positioned as an international reference.

\section{Acknowledgement}

Universidad de A Coruña (UDC).Consejo Económico y Social de Galicia (CES). Norvento Energías Renovables.
[1] F. Miguélez, La energía que viene del mar, Netbiblo La Coruña (2009).

[2] Balance Enerxético de Galicia 2006, Instituto Enerxético de Galicia - INEGA, Santiago de Compostela (2008), pp. 10-12.

[3] I. Troen, E.L. Petersen, European Wind Atlas, Riso National Laboratory, Roskilde (1989).

[4] T. Montero, "Galicia 1500 quilómetros de costa para a investigación”, La Voz de Galicia, España, Publicado (31-052009).

[5] T. Montero, "Industria, enerxía e ecoloxía copan a investigación do mar”, La Voz de Galicia, España, Publicado (31-05-2009).

[6] John Callaghan, "Future Marine Energy - Results of the marine energy challenge: Cost competitiveness and growth of wave and tidal stream energy", Carbon Trust, Reino Unido (2006).

[7] ENERXE - Agenda Estratégica de Innovación, Plataforma Tecnolóxica Galega de Enerxía, España (2009).

[8] G. Jourden, P. Marchand, Des énergies marines en Bretagne: à nous de jouer, CESR Bretagne, Francia (2009).

[9] A. Grandío, Ordenación de los Espacios Litorales en Galicia, Netbiblo, La Coruña (2005).

[10] Estrategia de Ahorro y Eficiencia Energética en España 2004-2012 (E4), Plan de Acción 2008-2012, Ministerio de Industria, Turismo y Comercio, España (2007).

[11] Plan Galego de Investigación, Desenvolvemento e InnovaciónTecnolóxica 2006-2010, Xunta de Galicia Consellería de Innovación e Industria - D.X. de I+D+i, España (2006).

[12] Plan Nacional de Investigación Científica, Desarrollo e Innovación Tecnológica 2008-2011, Comisión Interministerial de Ciencia y Tecnología, España (2007).

\section{References}

